\title{
Thyrotrophin-releasing hormone receptor 1 and prothyrotrophin-releasing hormone mRNA expression in the central nervous system are regulated by suckling in lactating rats
}

\author{
Åse-Karine Fjeldheim ${ }^{1}$, Per Ivar Høvring ${ }^{1}$, Ole-Petter Løseth ${ }^{1}$, Per Wiik Johansen ${ }^{2}$, Joel C Glover ${ }^{3}$, Vilborg Matre ${ }^{4}$, \\ Ole Kristoffer Olstad ${ }^{5}$, Sjur Reppe ${ }^{1}$, Jan O Gordeladze ${ }^{1}$, S Ivar Walaas ${ }^{1}$ and Kaare M Gautvik ${ }^{1,5}$ \\ ${ }^{1}$ Institute of Basic Medical Science, Department of Biochemistry, University of Oslo, PO Box 1112 Blindern, N-0317 Oslo, Norway, ${ }^{2}$ Department of \\ Clinical Pharmacology, Rikshospitalet University Hospital, N-O027 Oslo, Norway, ${ }^{3}$ Department of Physiology, University of Oslo, PO Box 1103 \\ Blindern, N-0317 Oslo, Norway, ${ }^{4}$ Department of Molecular Biosciences, University of Oslo, PO Box 1041 Blindern, N-0316 Oslo, Norway and \\ ${ }^{5}$ Department of Clinical Chemistry, Ullevål University Hospital, N-0407 Oslo, Norway
}

(Correspondence should be addressed to K M Gautvik, Institute of Basic Medical Science, Department of Biochemistry, University of Oslo, PO Box 1112 Blindern, N-0317 Oslo, Norway; Email: k.m.gautvik@medisin.uio.no)

\begin{abstract}
Background: The accepted function of the hypothalamic peptide, thyrotrophin-releasing hormone (TRH), is to initiate release of thyrotrophin (TSH) from the pituitary. A physiological role for TRH in lactating rats has not yet been established.

Methods: Tissues were prepared from random-cycling and lactating rats and analysed using Northern blot, real time RT-PCR and quantitative in situ hybridisation.

Results: This study demonstrates that TRH receptor 1 (TRHR1) mRNA expression is up-regulated in the pituitary and in discrete nuclei of the hypothalamus in lactating rats, while proTRH mRNA expression levels are increased only in the hypothalamus. The results were corroborated by quantitative in situ analysis of proTRH and TRHR1. Bromocriptine, which reduced prolactin (PRL) concentrations in plasma of lactating and nursing rats, also counteracted the suckling-induced increase in TRHR1 mRNA expression in the hypothalamus, but had an opposite effect in the pituitary. These changes were confined to the hypothalamus and the amygdala in the brain.

Conclusions: The present study shows that the mechanisms of suckling-induced lactation involve region-specific regulation of TRHR1 and proTRH mRNAs in the central nervous system notably at the hypothalamic level. The results demonstrate that continued suckling is critical to maintain plasma prolactin (PRL) levels as well as proTRH and TRHR1 mRNA expression in the hypothalamus. Increased plasma PRL levels may have a positive modulatory role on the proTRH/TRHR1 system during suckling.
\end{abstract}

European Journal of Endocrinology 152 791-803

\section{Introduction}

Administration of thyrotrophin-releasing hormone (TRH) stimulates release of prolactin (PRL) and thyrotrophin (TSH) from the pituitary gland in humans and animals (1-6). TRH is accepted as the physiological releasing hormone for TSH. In contrast, the role of TRH in controlling PRL secretion is less clear (7-9). It is generally accepted that PRL is under major physiological inhibitory control from the hypothalamus via dopaminergic pathways, and that a rise in PRL secretion occurs when dopamine release is reduced $(8,10,11)$. During pregnancy and parturition in humans there is a progressive and massive increase in PRL secretion, resulting in maintained elevated levels of the hormone in plasma. These changes are associated with initiation of lactation. In lactating women, a substantial increase in circulating PRL concentration occurs during suckling while TSH is unchanged $(1,2)$. Also, in rats, suckling has only a small effect on the concentration of TSH in plasma compared with the substantial elevation of PRL observed $(9,12,13)$. Therefore, if TRH is involved in PRL secretion and lactation, it probably does not act as a releasing hormone, but as a modulator of synaptic activity. Contrasting results regarding the effect of TRH immunoneutralisation on suckling-induced PRL release have been reported $(9,14)$. Suckling has been 
shown to have a positive effect on proTRH mRNA expression in the rat paraventricular nucleus (PVN) (15). At present, it is still uncertain if the TRH/TRH receptor 1 (TRHR1) system is involved in the suckling reflex. In the present study we wanted to examine if suckling leads to changes in the expression of proTRH and/or TRHR1 mRNA in identified regions of the central nervous system (CNS) and in the pituitary gland, using Northern blot analysis and real time RT-PCR combined with quantitative in situ hybridisation. Our working hypothesis was that possible changes in the TRH/TRHR1 system would be dependent on the duration and intensity of suckling, and therefore would be easier to detect after a longer duration of suckling. In an attempt to study the possible influence of a reduced plasma PRL level on these parameters, we used the dopamine D2 receptor agonist, bromocriptine, which also inhibits suckling-induced PRL secretion.

\section{Materials and methods}

\section{Animals and tissue preparation}

Female Wistar rats (Taconic Europe, Ry, Denmark) weighing $290-340 \mathrm{~g}$, had access to males of proven fertility. The experimental protocol was approved by the Norwegian National Committee of Animal Research prior to the experiments. The female rats which were housed individually prior to delivery gave birth to six or eight pups. Care was taken not to disturb the mothers, and the litter size was therefore not changed. Normal suckling and nesting behaviour were observed in groups II, III and IV. The only access to food was breast feeding. After a brief $(1 \mathrm{~min})$ exposure to $\mathrm{CO}_{2}$-gas, about $2 \mathrm{ml}$ heparinised blood was obtained by heart puncture before the rats were killed by decapitation. The brain and other tissue samples were dissected from the mothers immediately after death using a carefully designed and standardised protocol (16). The tissues were directly frozen on dry ice or in liquid $\mathrm{N}_{2}$. Horizontal brain sections $(15 \mu \mathrm{m})$ were cut on a cryostat, mounted on silane-treated slides and stored at $-80^{\circ} \mathrm{C}$ until further processing. The stereotactic coordinates of the sections were ascertained in accordance with the work of Paxinos and Watson (17). Plasma was obtained by centrifugation and frozen at $-20{ }^{\circ} \mathrm{C}$ for PRL measurements.

The following groups of rats were used: (a) group I, random-cycling, age-matched females - Northern analysis: $n=6$, quantitative in situ hybridisation (ISH): $n=3$; (b) group II, mothers nursing their pups for 20 days - Northern analysis: $n=9$, quantitative ISH: $n=3$; (c) group III, mothers nursing their pups for 19 days before removal of the pups during the last $24 \mathrm{~h}$ - Northern analysis: $n=6$; (d) group IV, nursing rats received bromocriptine $(1.25 \mathrm{mg} / \mathrm{kg})$ twice, by two separate subcutaneous injections on day 10 and day 15 after birth, and were otherwise treated as rats in group II - Northern analysis: $n=5$.

\section{Prolactin (PRL) determination}

PRL concentrations in plasma were measured by radioimmunoassay (RIA) as described previously (18). The lower limit of detection was $1.0 \mathrm{ng} / \mathrm{ml}$ and intra- and interassay variations were $8.5 \%$ and $11 \%$ respectively.

\section{Preparation of total RNA and Northern blot analysis}

Total RNA was isolated according to a modification of a previously described method (19). Total RNA was extracted by homogenisation of tissue in guanidine thiocyanate (GTC) buffer consisting of $5 \mathrm{~mol} / \mathrm{l} \mathrm{GTC}$, $25 \mathrm{mmol} / \mathrm{l} \mathrm{Na}$-citrate, $\mathrm{pH}$ 7.0, 0.5\% sodium lauroyl sarcosine (SLS) and 2-mercaptoethanol. The tissue homogenate was centrifuged in a caesium chloride $(\mathrm{CsCl})$ gradient in a Beckman Ultracentrifuge (Beckman Instruments $\mathrm{GmBH}$ ) for $15 \mathrm{~h}$ at 36000 r.p.m. at room temperature. After centrifugation, the RNA was dissolved in a buffer consisting of $10 \mathrm{mmol} / \mathrm{l}$ Tris $(\mathrm{pH}$ 7.0 ), $5 \mathrm{mmol} / \mathrm{l}$ EDTA (pH 8.0) and 1\% SDS. Proteins were removed from the RNA solution by extracting with phenol and then with phenol and CHISAM (chloroform:isoamyl alcohol, 24:1) together. After precipitation with $1 / 10$ volume $3 \mathrm{~mol} / \mathrm{l} \mathrm{Na}$-acetate $(\mathrm{pH} 5.2)$ and $2.5-3 \times$ volume $100 \%$ ethanol, and washing with $70 \%$ ethanol, RNA was dissolved in sterile water and quantitated by a spectrophotometer at $260 \mathrm{~nm}$ (4054 UV/Visible Spectrophotometer Ultrospec Plus, LKB-biochem, Amersham Pharmacia Biotech Inc.).

After denaturation (50\% formamide, 6\% formaldehyde followed by heating $\left(15 \mathrm{~min}\right.$ at $\left.50^{\circ} \mathrm{C}\right)$ and cooling on ice), total RNA $(20-40 \mu \mathrm{g})$ was separated in $1.5 \%$ agarose gel $(6.7 \%$ formaldehyde, $20 \mathrm{mmol} / \mathrm{l} \mathrm{Na}-$ phosphate, $\mathrm{pH}$ 7.0) and transferred to a nylon membrane (Hybond $\mathrm{N}+$, Amersham Pharmacia Biotech Inc.) using $20 \times \mathrm{SSC}(150 \mathrm{mmol} / \mathrm{l} \mathrm{NaCl}, 15 \mathrm{mmol} / \mathrm{l}$ Na-citrate, $\mathrm{pH}$ 7.0) and a capillary-blotting technique (20). The membrane was UV crosslinked for $2 \mathrm{~min}$ using a UV transilluminator and baked at $80^{\circ} \mathrm{C}$ for $2 \mathrm{~h}$. The filters were prehybridised, hybridised, washed and stripped according to the manufacturer's instructions. Radioactively labelled cDNA probes of rat (r) proTRH or rTRHR1 $\left(5 \times 10^{6}\right.$ c.p.m. $/ \mathrm{ml}$ each $)$ or human glyceraldehyde-3-phosphate dehydrogenase (hGAPDH, $1 \times 10^{6}$ c.p.m./ml) were added to the hybridisation solution. Washing was carried out twice in $2 \times \mathrm{SSPE} / 0.1 \% \mathrm{SDS}$ for $15 \mathrm{~min}$ at room temperature, once in $1 \times \mathrm{SSPE} / 0.1 \% \mathrm{SDS}$ for $20 \mathrm{~min}$ at $65^{\circ} \mathrm{C}$ and at least once in $0.1 \times \mathrm{SSPE} / 0.1 \%$ SDS for $15 \mathrm{~min}$ at $65^{\circ} \mathrm{C}$. The membranes were exposed to Hyperfilm (Amersham Pharmacia Biotech Inc) at $-70^{\circ} \mathrm{C}$ for several days. Variation in loading was corrected for by normalisation to hGAPDH mRNA. 


\section{Probe synthesis and labelling for Northern hybridisation}

Three different cDNA probes were used: rproTRH, rTRHR1 and hGAPDH. The probes were made by random priming and labelled with ${ }^{32} \mathrm{P}$ according to the manufacturer's instructions (Oligolabelling Kit, Amersham Pharmacia Biotech Inc.).

The rproTRH cDNA (700 bp) was made by reverse transcriptase-polymerase chain reaction (RT-PCR). The RT reaction used $0.5 \mu \mathrm{g}$ total RNA of a rat hypothalamus and $0.5 \mu \mathrm{g}$ Oligo dT15 (Promega). After incubation at $70^{\circ} \mathrm{C}$ for $10 \mathrm{~min}$ the solution was rapidly cooled on ice. Reaction buffer (First Strand $5 \times$ buffer, Promega), $0.5 \mathrm{mmol} / \mathrm{l} \mathrm{dNTP}$ and $200 \mathrm{U}$ M-MLV-RT (Promega) were then added to a final volume of $20 \mu \mathrm{l}$ before incubation at $42{ }^{\circ} \mathrm{C}$ for $1 \mathrm{~h}$. The reaction was stopped at $95^{\circ} \mathrm{C}$ for $5 \mathrm{~min}$. The specific primers (Gibco BRL) in PCR were: forward primer 5'-CTGCTGGCTCTGGCTTTGAT-3', reverse primer 5'-CAGAGGTTCGTTGTCCCAG-3'. The PCR mixture consisted of $1 / 10$ of the RT mixture, reaction buffer, $0.1 \mathrm{mmol} / \mathrm{l} \mathrm{dNTP}, 0.2 \mu \mathrm{mol} / \mathrm{l}$ of each primer and $2 \mathrm{U}$ AmpliTaq Gold DNA polymerase (Perkin Elmer, Hvidovre, Senmark). The reaction mixture was heated to $95^{\circ} \mathrm{C}$ for $3-5 \mathrm{~min}$ before addition of polymerase (hot-start), followed by 35 cycles of denaturing at $95^{\circ} \mathrm{C}$ for $1 \mathrm{~min}$, annealing at $50^{\circ} \mathrm{C}$ for $1 \mathrm{~min}$ and extension at $72^{\circ} \mathrm{C}$ for $1 \mathrm{~min}$. An extra extension at $72{ }^{\circ} \mathrm{C}$ for $10 \mathrm{~min}$ was used at the end. The PCR products were cloned into the pCRII-TOPO vector according to the manufacturer's instructions (Invitrogen), and their sequences confirmed.

An rTRHR1 specific cDNA clone (700 bp) (21) showing a sequence homology to the rTRHR2 $(22,23)$ of less than $30 \%$, was used. The rTRHR1 gave a single mRNA species of $3.8 \mathrm{~kb}$ on all Northern blots, different from the $9.4 \mathrm{~kb}$ mRNA reported for the rTRHR2 (22, 23). An RT-PCR-based hGAPDH cDNA probe (450 bp) was made by using primers from Clontech (\#5405-1). In the RT reaction, $1 \mu \mathrm{g}$ total RNA from a human TPXM cell line was used. The PCR was performed using AmpliTaq Gold polymerase (Perkin Elmer) according to the manufacturer's instructions, modified to 35 cycles and an annealing temperature of $60^{\circ} \mathrm{C}$.

\section{Real time RT-PCR for TRH degradation enzyme (TRHDE) and $\beta$-actin}

Four micrograms total RNA were used for reverse transcription. Twenty microlitres cDNA solutions were diluted to $100 \mu \mathrm{l}$ with carrier MS2 virus DNA $(10 \mu \mathrm{g} / \mu \mathrm{l})$. Two microlitres cDNA solution were used in each PCR reaction. Real time RT-PCR was performed as described (24). Amplification of cDNA was performed in triplicate (LightCycler, cat. no. 2239264; Roche Diagnostics) which showed a variation of less than $10 \%$ for $\beta$-actin and TRHDE. The rat specific primers (Invitrogen Life Technologies) used in the PCR were: $\beta$-actin, forward primer 5'-GCCATCTCTTGCTCGAAGTC-3', reverse primer 5'GCCTACAGCTTGACCACCACA-3'; TRHDE, forward primer 5'-TCTGGAGGAGTAAGGCCAGA-3', reverse primer 5'-TTGGGTGGACGATGTACAGA-3'.

\section{In situ hybridisation (ISH)}

The ISH was performed by a modified version of the protocol described by Hoover and Goldman (25) as described by Torp et al. (26). Fixed (4\% formaldehyde) $15 \mu \mathrm{m}$ sections were rehydrated through graded alcohols $(90 \%, 80 \%, 70 \%, 50 \%)$, rinsed in $2 \times \mathrm{SSC}$ $(0.3 \mathrm{~mol} / \mathrm{l} \mathrm{NaCl}, 0.03 \mathrm{~mol} / \mathrm{l}$ Na-citrate, $\mathrm{pH} 7.0)$ and digested with Proteinase K $(10 \mu \mathrm{mol} / \mathrm{l} / \mathrm{ml})$ in $0.1 \mathrm{~mol} / \mathrm{l}$ Tris $-\mathrm{HCl}$ and $0.05 \mathrm{~mol} / \mathrm{l}$ EDTA for $15 \mathrm{~min}$ at $37^{\circ} \mathrm{C}$. The sections were then acetylated with $0.25 \%$ acetic anhydride in $0.1 \mathrm{~mol} / \mathrm{l}$ triethanolamine ( $\mathrm{pH} 8.0$ ) for $10 \mathrm{~min}$ at room temperature, dehydrated through graded alcohols $(50 \%, 70 \%, 80 \%, 90 \%)$ and dried. The sections were incubated in hybridisation solution $(0.01 \mathrm{~mol} / \mathrm{l}$ Tris- $\mathrm{HCl}, \mathrm{pH} 7.4,50 \%$ formamide, $0.3 \mathrm{~mol} / \mathrm{l} \mathrm{NaCl}, 0.001 \mathrm{~mol} / \mathrm{l}$ EDTA, $10 \%$ dextran sulphate and $1 \%$ blocking solution) containing $4 \mathrm{ng}$ (rproTRH, antisense and sense) or $12 \mathrm{ng}$ (rTRHR1, antisense and sense) of digoxigenin-labelled RNA probe per $\mu$. The riboprobes were made by in vitro transcription and labelled with digoxigenin (DIG)UTP according to the manufacturer's instructions (DIG RNA Labelling Kit, Boehringer Mannheim). The slides were covered with Parafilm and placed in a humid chamber for $16-20 \mathrm{~h}$ at $55^{\circ} \mathrm{C}$. Following hybridisation, the sections were rinsed for several times in $2 \times \mathrm{SSC}$ at room temperature $(3 \times 5 \mathrm{~min}$ and $1 \times 30 \mathrm{~min}$ ) before they were immersed in $2 \times$ SSC containing $50 \%$ formamide at $55^{\circ} \mathrm{C}$ for $30 \mathrm{~min}$. The formamide was removed by washing with $2 \times$ SSC at room temperature $(2 \times 10 \mathrm{~min})$. Unhybridised mRNA and RNA probes were removed from the sections using ribonuclease A (RNaseA, $50 \mu \mathrm{g} / \mathrm{ml})$ in $0.01 \mathrm{M}$ Tris-HCl, $\mathrm{pH} 7.4, \quad 0.3 \mathrm{~mol} / \mathrm{l} \mathrm{NaCl}$ and $0.001 \mathrm{~mol} / \mathrm{l}$ EDTA at $37^{\circ} \mathrm{C}$ for $30 \mathrm{~min}$. The sections were then rinsed in the same solution without RNaseA, at $60^{\circ} \mathrm{C}$ for $30 \mathrm{~min}$ followed by incubating at room temperature in a washing/blocking solution ( $2 \times$ SSC, $0.05 \%$ Triton X-100, 1\% blocking solution) for $3 \mathrm{~h}$.

The sections were rinsed with $1 \times$ maleate buffer $(0.1 \mathrm{~mol} / \mathrm{l}$ maleic acid and $0.15 \mathrm{~mol} / \mathrm{l} \mathrm{NaCl}, \mathrm{pH} 7.5)$ for $2 \times 5 \mathrm{~min}$ and immersed in $1 \times$ maleate buffer containing alkaline phosphatase-conjugated DIG antibody (1:3000), $0.3 \%$ Triton X-100 and 1\% Blocking solution for $16-20 \mathrm{~h}$ at $4{ }^{\circ} \mathrm{C}$. The sections were rinsed in $1 \times$ maleate buffer for $2 \times 5 \mathrm{~min}$, once in $1 \times$ Buffer \#3 $(0.1 \mathrm{~mol} / \mathrm{l}$ Tris, $0.1 \mathrm{~mol} / \mathrm{l} \mathrm{NaCl}$, $0.05 \mathrm{~mol} / \mathrm{l} \mathrm{MgCl}_{2}$ ) for $10 \mathrm{~min}$ and then incubated with chromogen solution (nitroblue tetrazolium 
(NBT), 5-bromo-4-chloro-3-indolyl-phosphate (BCIP) and $2 \mathrm{mmol} / \mathrm{l}$ levamisole in $1 \times$ maleate buffer) at $37^{\circ} \mathrm{C}$ in the dark for $5 \mathrm{~h}$ (rproTRH) or $8 \mathrm{~h}$ (rTRHR1). The reaction was stopped by immersing the sections in a solution consisting of $10 \mathrm{mmol} / \mathrm{l}$ Tris, $\mathrm{pH} 7.5,1 \mathrm{mmol} / \mathrm{l}$ EDTA, $\mathrm{pH} 8.0$ and $0.9 \%$ $\mathrm{NaCl}$. Sense riboprobes were used as negative controls. The specimens to be compared were given identical treatments to compensate for possible non-linearity in, for example, chromophore deposition.

\section{Quantitative ISH of rproTRH mRNA and TTRHR1 mRNA}

From three brains of rats from groups I and II, every fifth section $(15 \mu \mathrm{m})$ from the hypothalamus was hybridised with rproTRH or rTRHR 1 antisense probes. Control hybridisations with the same probes in sense orientation were carried out for every 49th and 50th section. Areas of the hypothalamus in which either rproTRH mRNA or rTRHR1 mRNA (or both) were highly expressed were selected for quantification. Typically, 10-16 sections were found to cover the area of interest. The analyses were carried out by three persons quantifying blind to the protocol using both manual cell count as well as image processing employing a pixel program system (Scion Image, NIH, Frederick, UA, Frederick, UA, USA).

The slides were photographed using a Leica MPS 60 camera (Kodak EPY64T film) on a Leica HC microscope, scanned using a Nikon Super coolscan 5000 and transferred into Photoshop 7.0 (Adobe) for analysis. Images to be used for quantification with the Scion Image program were first converted to black and white using the greyscale function. After importing the images into Scion Image, the background was subtracted using the 'processsubtract background' function and all grey values in the images converted to different densities of either black or white pixels using the dither function. This gives a pixilated representation of the original grey scale image having a scale from 0 to 256 where 0 represents all white pixels and 256 represents all black pixels. The number of black pixels was counted in each image within a defined area of interest. This number was in each case divided by the area of the region, converting it to a pixel density value. From this value, the corresponding value from the sense image was subtracted in order to correct for background. The corrected value was then multiplied by the corresponding area and the sum of values from sections throughout the brain region of interest provided the final number of total ISH signals for one nucleus/region. Hence, variation in pixel density values represents differences both in the numbers of positive cells as it relates to the total areas of signal, and in signal intensity in each positive cell, relating to the intensity of signal per area.

\section{Statistical analysis}

The results are presented as mean values \pm S.E.M. For experiments with three or more groups, the KruskalWallis non-parametric test, followed by a Dunn's Multiple Comparison test were used to calculate the levels of significance ( $P$ values) for $n=3-9$ rats per group using GraphPad Prism program version 4.00 (GraphPad Software Inc., San Diego, CA, USA). To compare the two groups examined in the ISH analysis, a Mann-Whitney test was used to calculate the levels of significance ( $P$ values).

\section{Results}

\section{Regional effects of suckling on TRHR1 mRNA expression in hypothalamus}

Northern blot analysis from dissected hypothalami shows that rats in group II had a 2.6-fold $(P<0.001)$ increase in relative values of TRHR 1 mRNA compared with random-cycling control animals in group I (Fig. 1). In rats subjected to a reduced lactating period due to early removal of the pups (group III), the TRHR1 mRNA expression almost returned to that of the non-lactating rats (group I).

Groups I and II were also compared using complementary quantitative ISH performed on sections of hypothalamic regions selected for a high expression of either TRHR1 and/or proTRH mRNA, namely the supraoptic nucleus (SON), the paraventricular nucleus $(\mathrm{PVN})$, the lateral mammilary body (LM) and the lat-

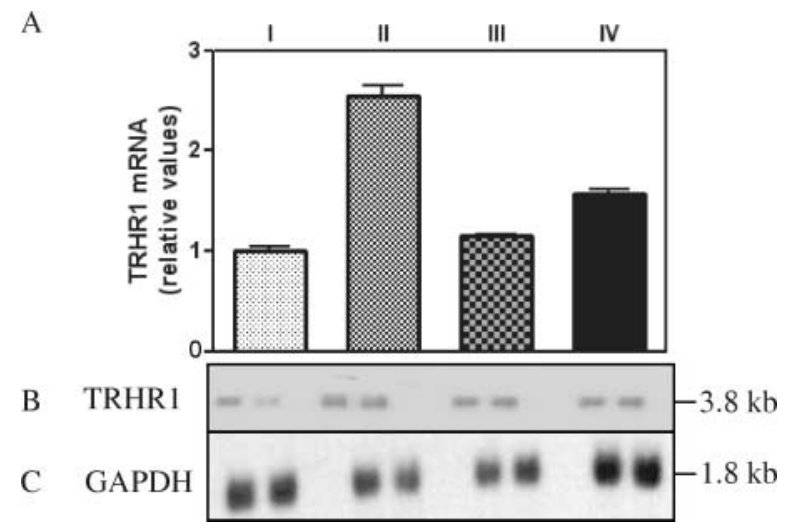

Figure 1 The effects of suckling and bromocriptine treatment on hypothalamic TRHR1 mRNA. Northern blot analyses using $20 \mu \mathrm{g}$ hypothalamic total RNA per lane from random-cycling control rats (group I) and from three groups (II, III and IV) of lactating mothers (see Materials and methods) are shown. The results are mean values \pm S.E.M. Group II compared with group I or group III, $P<0.01$. Group II compared with group IV, $P<0.05$. (A) TRHR1 mRNA expression in the four different groups as assessed by semi-quantitative densitometric scans. (B and C) Representative Northern blot analysis of TRHR1 and the internal standard GADPH in the four different groups. The films were exposed for 10 days (TRHR1) or 2 days (GAPDH) respectively. 
eral preoptic area (LPO), and the substantia nigra, pars compacta (SNC) in the mesencephalon. Quantification was carried out by cell count and by expressing images from the area of interest as pixel density and by using the Scion Image program (NIH, see Materials and methods). The two approaches gave corresponding results as shown in Fig. 2. In group II a marked upregulation was detected in the SON (cell count (A1): 2.7-fold, $P<0.05$; image processing (A2): 1.4-fold, $P=0.1)$. Although no statistical difference was found in the PVN, a small increase could be detected (cell count (B1): 1.3-fold, $P=0.7$; image processing (B2): 1.2-fold, $P=0.2$ ). TRHR1 mRNA expression was most markedly increased in group II in the LM (cell count (C1): 4.1-fold, $P<0.05$; image processing (C2): 3.8-fold, $P<0.05)$. Typical histological pictures showing TRHR 1 mRNA-positive neurons in the three different regions are shown in Fig. 3. Note the more dense areas of TRHR 1 mRNA-positive neurons in the SON compared with the PVN and LM.

\section{TRHR1 mRNA in other CNS regions and in the pituitary}

TRHR 1 mRNA expression levels were reduced by about $50 \%(P<0.05)$ in the amygdala in group II compared with controls (group I) animals (Table 1). Otherwise, no significant changes were found between the experimental groups in the hippocampus, cortex or cerebellum as measured by Northern blot analysis. In the thalamus and striatum, TRHR 1 mRNA was only faintly present, and no variation was found between the groups (data not shown).

In the pituitary, suckling resulted in a 3.2-fold $(P<0.01)$ increase in relative expression levels of TRHR1 mRNA in rats of group II compared with random-cycling females (group I, Fig. 4). Following reduced suckling stimulus the expression of TRHR1 mRNA for rats in group III was reduced, but was still 1.6-fold above the non-lactating control group.

\section{Suckling-induced regional effects on proTRH mRNA in the hypothalamus}

Results from the hypothalamus show that rats in group II had a 1.6-fold $(P<0.001)$ increase in relative values of proTRH mRNA compared with group I rats as judged by Northern blot analysis (Fig. 5). In the absence of a regular suckling stimulus, the level of proTRH mRNA in the hypothalamus was not maintained, but declined almost to group I levels after $24 \mathrm{~h}$ (group III versus group II).

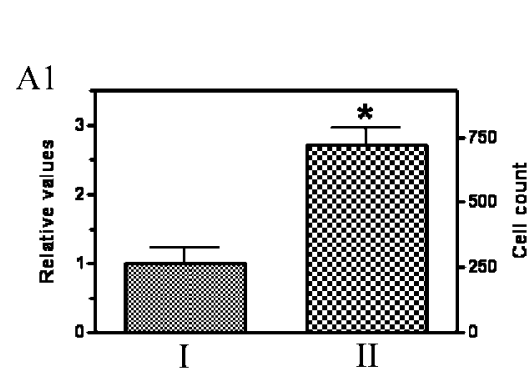

PVN

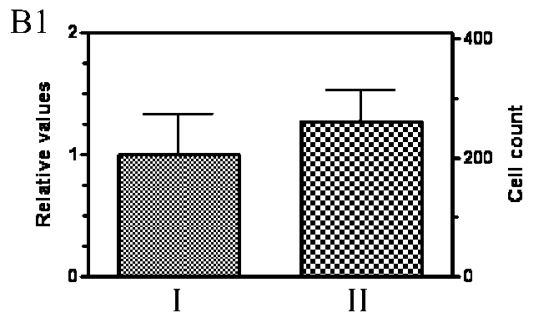

LM

C1

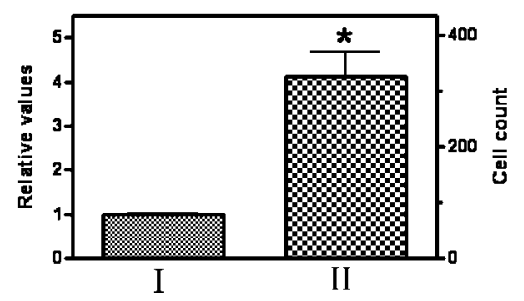

A2

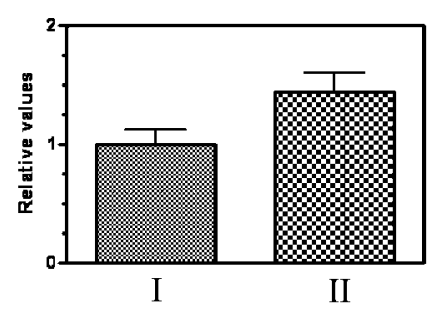

B2

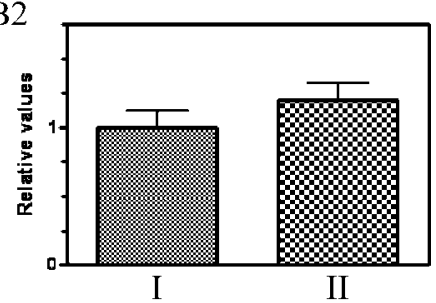

$\mathrm{C} 2$

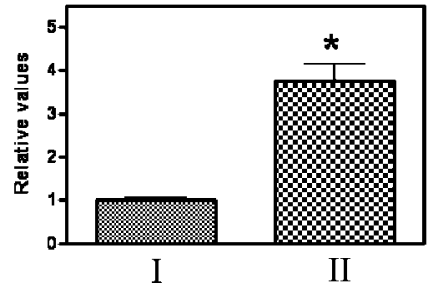

Figure 2 Quantitative in situ hybridisation (ISH) of TRHR1 mRNA in the hypothalamic nuclei, SON, PVN and LM. Results from manual cell counts (A1, B1 and $C 1)$ and from image processing giving pixel densities (A2, B2 and C2) in three different hypothalamic regions taken from rats in groups I and II (see Materials and methods) are shown. The bars represent normalised mean values \pm S.E.M. for sections of hypothalamus of three rats from groups I and II (left $y$-axis). In addition, the right $y$-axis in the figures gives the number of positive cells for the manual count (A1, B1 and C1). Total numbers of sections per nucleus were 10-16. (A) Supraoptic nucleus (SON). (B) Paraventricular nucleus (PVN). (C) Lateral mammillary body (LM). ${ }^{*} P<0.05$. 

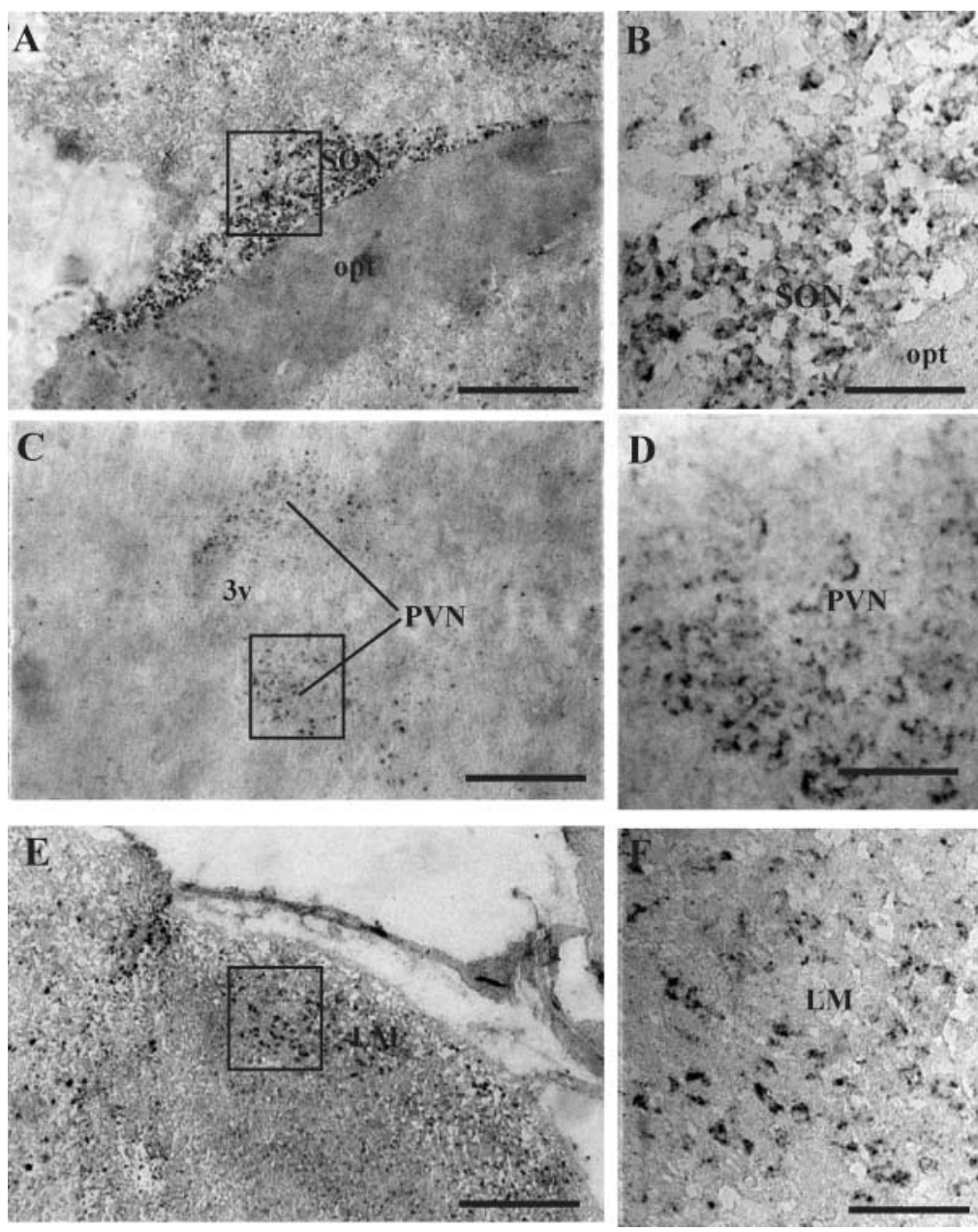

Results from the quantitative ISH analysis (Fig. 6) demonstrated that although there was a relative increase in proTRH mRNA in the SON of group II rats, the results did not reach statistical significance (cell count (A1): 1.3-fold, $P=0.35$; image processing (A2): 1.5 -fold, $P=0.1$ ). The highest proTRH mRNA increases in group II compared with group I animals were in the PVN (cell count (B1): 1.7-fold, $P=0.2$; image processing (B2): 1.4-fold, $P<0.05$ ) and in the LPO (cell count (C1): 2.4-fold, $P<0.05$; image processing (C2): 1.9-fold, $P<0.05)$. The SNC in the mesencephalon also showed an increase in proTRH mRNA expression in group II compared with group I animals (cell count (D1): 1.8-fold, $P=0.1$; image processing (D2): 1.3-fold, $P<0.05$ ).

Typical histological pictures showing proTRH mRNA-positive neurons in the four different regions are shown in Fig. 7. Note the more dense areas of proTRH positive neurons in the SON and LPO compared with the PVN and SNC.

Table 1 The effects of suckling and bromocriptine treatment (see Materials and methods) on TRHR1 mRNA expression. The mRNA expression was evaluated by Northern blot analysis and quantified by densitometric scanning. Values for TRHR1 mRNAs are relative to those of GAPDH and normalised to group I. Mean values \pm S.E.M. of 3-6 rats $(n)$. For $n=2$, the mean values and range are given.

\begin{tabular}{lcccr}
\hline & \multicolumn{4}{c}{ Group } \\
\cline { 2 - 5 } Tissue & $\mathrm{I}$ & $\mathrm{II}$ & $\mathrm{III}$ & $\mathrm{I}$ \\
\hline Amygdala & $1.00 \pm 0.36(4)$ & $0.50 \pm 0.11^{*}(6)$ & $1.15 \pm 0.35(4)$ & $0.51 \pm 0.12^{*}(3)$ \\
Hippocampus & $1.00 \pm 0.12(4)$ & $1.00 \pm 0.16(4)$ & N.D. & $0.84 \pm 0.26(4)$ \\
Cortex & $1.00 \pm 0.05(2)$ & $0.92 \pm 0.08(4)$ & N.D. & $0.88 \pm 0.04(4)$ \\
Cerebellum & $1.00 \pm 0.15(2)$ & $0.97 \pm 0.13(4)$ & N.D. & $0.81 \pm 0.18(2)$ \\
\hline
\end{tabular}

* $P<0.05$ compared with group I. N.D., not determined. 
A

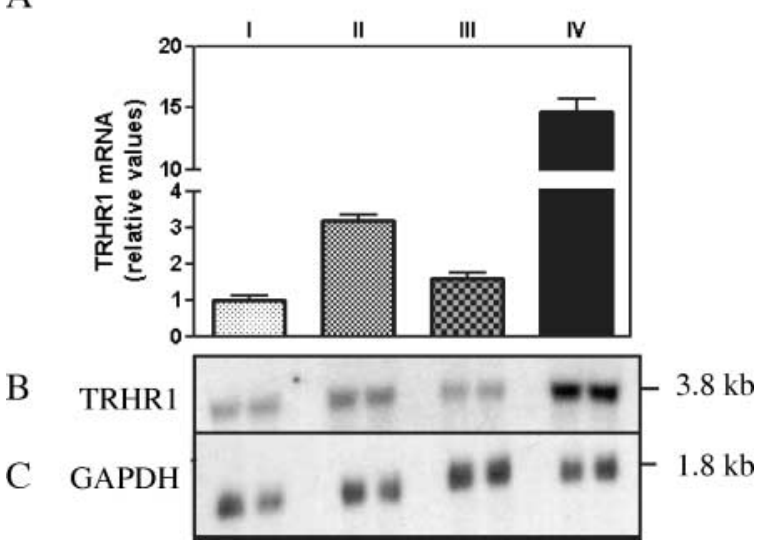

Figure 4 The effects of suckling and bromocriptine treatment on pituitary TRHR 1 mRNA. Northern blot analyses using $20 \mu \mathrm{g}$ pituitary total RNA per lane from random-cycling control rats (group I) and from three groups (II, III and IV) of lactating mothers (see Materials and methods) are shown. The results are mean values \pm S.E.M. Groups II and IV versus group I or group III, $P<0.01$. Group III versus group I, $P<0.05$. Group IV versus group II, $P<0.01$. (A) TRHR1 mRNA expression in the four different groups assessed by semi-quantitative densitometric scans. (B and C) Representative Northern blot analysis of TRHR1 and the internal standard GADPH in the four different groups. The films were exposed for 3 days (TRHR1) or 2 days (GAPDH) respectively.

\section{ProTRH mRNA in other CNS regions and in the pituitary}

No significant changes in proTRH mRNA expression between the groups were observed in thalamus, cortex and cerebellum as measured by Northern blot analysis (data not shown). Due to the low amounts of proTRH mRNA in the pituitary, real time RT-PCR was used to measure the proTRH mRNA expression. However, no significant difference was found between the groups (data not shown). ProTRH mRNA expression could not be detected in either the striatum or the hippocampus.

\section{Alterations in TRHR1 and proTRH MRNA expressions caused by bromocriptine treatment}

Bromocriptine is known to inhibit PRL secretion through dopaminergic mechanisms (27). In order to analyse a possible association between changes in PRL plasma concentrations and TRHR1 and proTRH mRNA expression, we tested if bromocriptine led to alterations in TRHR 1 or proTRH mRNA expression in the pituitary and/or the brain. Plasma PRL concentrations were elevated about 25 -fold $(P<0.001)$ in the most suckling intensive group, group II (Table 2). Bromocriptine given to freely nursing rats reduced plasma PRL concentration by $2 / 3(P<0.05)$ (Table 2 , group IV) while removal of the pups dramatically lowered plasma PRL by about 5/6 (group III) compared
A
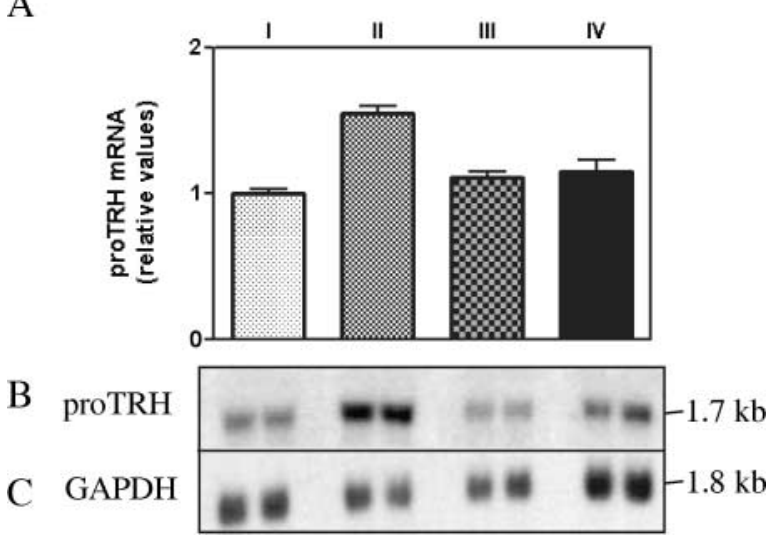

Figure 5 The effects of suckling and bromocriptine treatment on hypothalamic proTRH mRNA. Northern blot analyses using $20 \mu \mathrm{g}$ hypothalamic total RNA per lane from random-cycling control rats (group I) and from three groups (II, III and IV) of lactating mothers (see Materials and methods) are shown. The results are mean values \pm S.E.M. Group II compared with group I, $P<0.001$. Group II compared with group III, $P<0.05$. (A) proTRH mRNA expression in the four different groups as assessed by semi-quantitative densitometric scans. (B and $\mathrm{C}$ ) Representative Northern blot analysis of proTRH and the internal standard GADPH in the four different groups. The films were exposed for 4 days (proTRH) or 2 days (GAPDH) respectively.

with group II. However, the PRL levels were still elevated compared with the control group (group I). In the hypothalamus, this pharmacological intervention decreased the suckling-induced TRHR1 and proTRH mRNA expression by $63 \%$ and $73 \%$ respectively (Figs 1 and 5, group IV versus group II). Bromocriptine reduced the proTRH mRNA expression by about 30\% (group II versus group IV). Thereby, proTRH mRNA expression was reduced to the same level as in the random-cycling control animals (group I). In the pituitary, TRHR 1 mRNA expression surprisingly showed a further increase after bromocriptine treatment (6.2fold higher in group IV compared with group II animals, Fig. 4). This is 15 -fold more than the values found in random-cycling females $(P<0.01)$.

\section{No effect of suckling on TRHDE mRNA expression}

To test if suckling had possible secondary, modulating effects on the other parts of the TRH system, we quantified the mRNA expression of the specific TRH degradation enzyme (TRHDE) in the pituitary and hypothalamus using real time RT-PCR (Table 3). No significant changes in TRHDE mRNA expression were observed between the various experimental groups.

\section{Discussion}

In the present study, we wanted to analyse whether suckling-induced lactation gave a recognisable 
SON

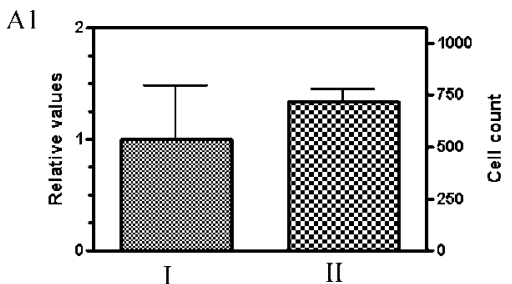

PVN

B1

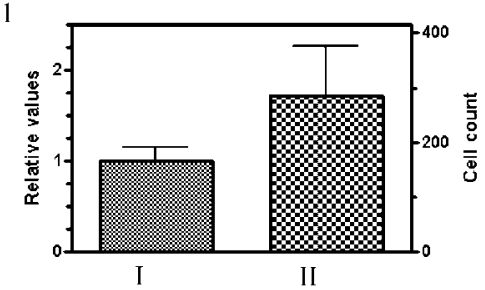

A2

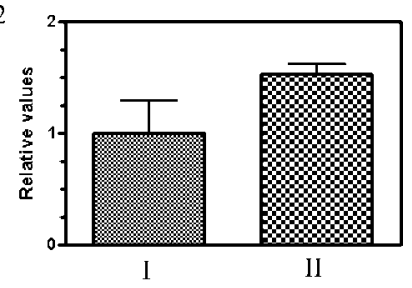

B2

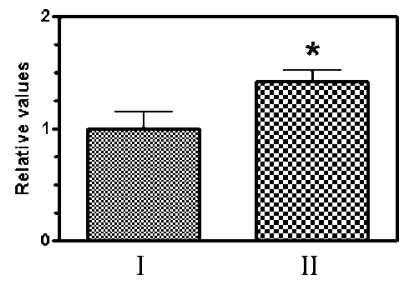

LPO

C1

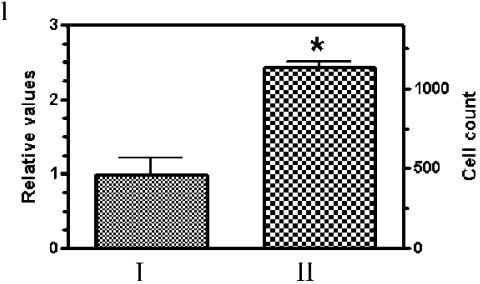

$\mathrm{SNC}$

D1

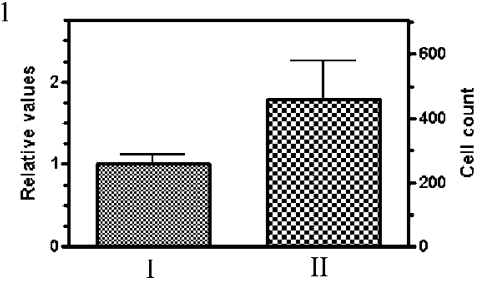

$\mathrm{C} 2$

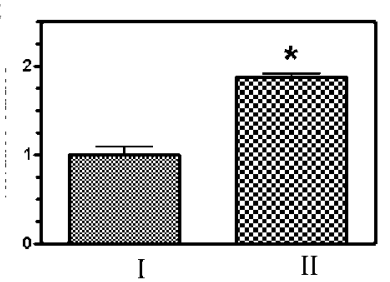

D2

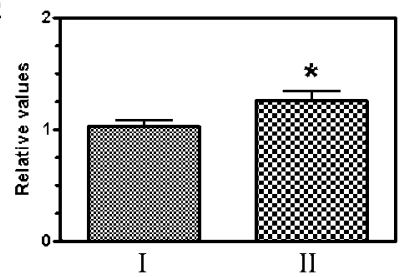

Figure 6 Quantitative in situ hybridisation (ISH) of proTRH mRNA in the hypothalamic nuclei (SON, PVN and LPO) and in the substantia nigra, pars compacta (SNC). Results from manual cell count (A1, B1, C1 and D1) and from image processing giving pixel densities (A2, B2, C2 and D2) in three different hypothalamic regions and the SNC from rats in groups I and II (see Materials and methods) are shown. The bars represent normalised mean values \pm S.E.M. for sections of hypothalamus of three rats from groups I and II (left $y$-axis). In addition, the right $y$-axis in the left panel gives the number of positive cells for the manual count (A1, B1 and C1). Total number of sections per nucleus were 10-16. (A) Supraoptic nucleus (SON). (B) Paraventricular nucleus (PVN). (C) Lateral preoptic area (LPO). (D) Substantia nigra, pars compacta (SNC). * $P<0.05$. molecular signature involving the proTRH/TRHR1 system in the hypothalamus and other areas of the CNS. Our experiments show for the first time an upregulation of rat TRHR 1 mRNA expression in the hypothalamus and in the pituitary during the physiological process of suckling-induced lactation (Figs 1 and 4). It is noteworthy that these changes were highly reversible and critically dependent on the suckling intensity. The marked difference between TRHR1 and proTRH mRNA expression in groups II and III (Figs 1, 4 and 5) was closely associated with the presence/absence of the suckling stimulus during the last $24 \mathrm{~h}$. A rapid regulation of proTRH mRNA expression in the hypothalamus has previously been described as already occurring after $30 \mathrm{~min}$ of suckling (15) and sucklinginduced serum PRL responses occur within 2-15 min in lactating women $(2,15)$. Nillni and co-workers have reported a five- and sixfold increase in hypothalamic preproTRH mRNA expression and in serum PRL respectively in lactating rats which had been separated from their pups for $6 \mathrm{~h}$ on postnatal day 4 , and then reunited with them for $45 \mathrm{~min}$ (28). Rats and humans both demonstrate a maximum increase in serum PRL during suckling after $30 \mathrm{~min}$ $(2,15)$. Thus, rapid neuroendocrine adaptations are followed by discrete changes in the neuronal molecular network associated with the suckling-lactation reflex.

Do the enhanced PRL secretion and plasma PRL levels directly influence proTRH and/or TRHR1 mRNA expression? In this study, plasma PRL concentrations were changed in two ways. In the first, removal of the suckling stimulus led to an approximate $85 \%$ reduction in plasma PRL levels. In the second, bromocriptine given to freely nursing rats which showed normal maternal and grooming behaviour, reduced plasma PRL by about 65\% (group IV versus group II, 

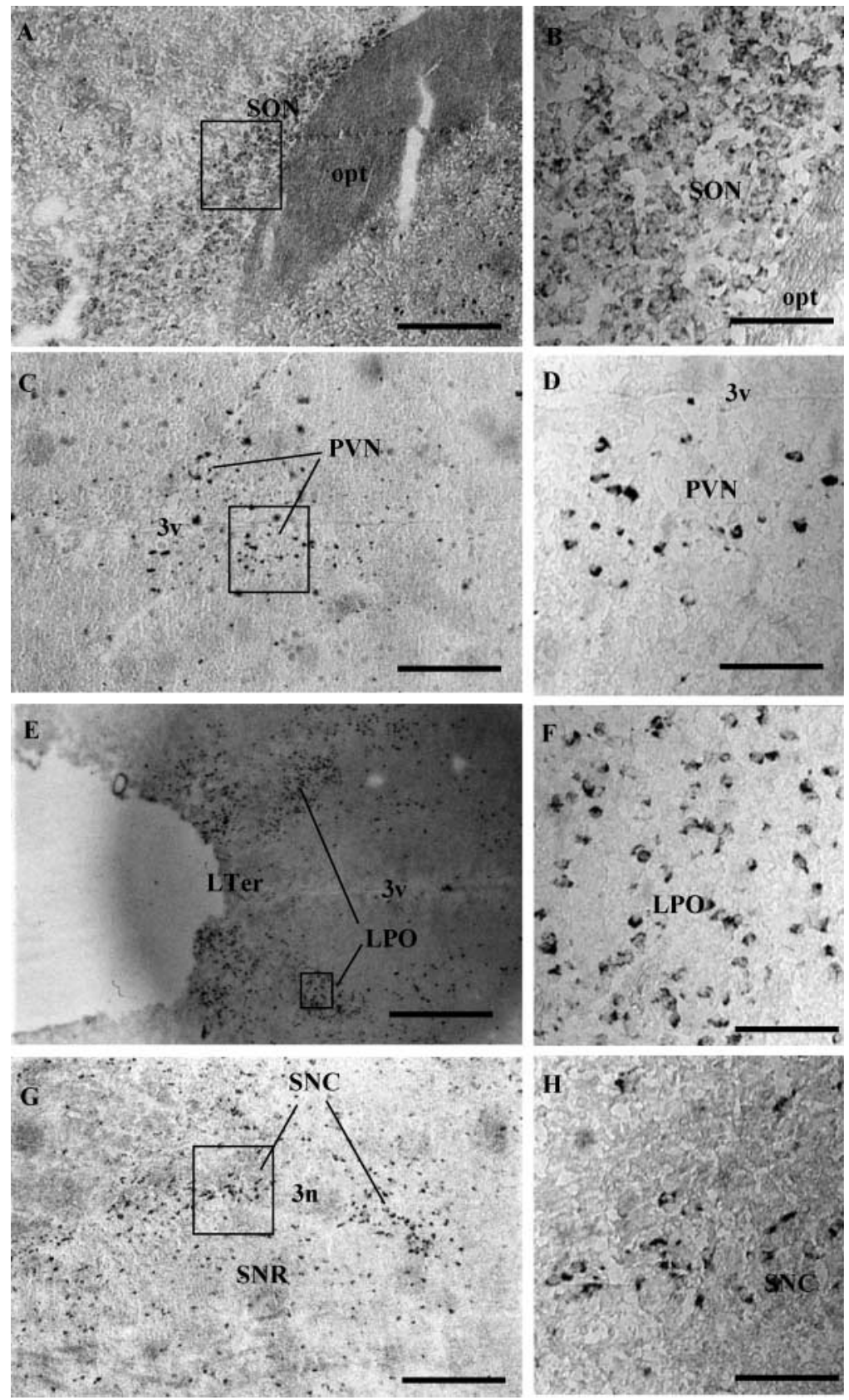

Figure 7 ISH analysis of proTRH mRNA in horizontal sections of rat brain. (A) Positively labelled cells in the supraoptic nucleus (SON) adjacent to the optic nerve (opt). The frame shows labelled cells, which are enlarged in (B). (C) Strongly labelled cells in the paraventricular nucleus (PVN) on both sides of the third ventricle (3v). (D) Enlargement of the cells within the frame shown in (C). (E) Strong ISH signals from neurons symmetrically located adjacent to the third ventricle $(3 \mathrm{v})$ in the lateral preoptic area (LPO). Note also strongly positive signals from groups of neurons anterior to LPO and lateral to the lamina terminalis (LTer). (F) Higher magnification of labelled cells in (E). (G) Positively labelled cells in the substantia nigra, pars compacta (SNC), and ventral tegmental area separated by the oculomotor nerve (3n) and located rostral to the substantia nigra, reticular part (SNR). (H) Enlargement of the cells in $(G)$. Scale bars: A, C and G, $240 \mu \mathrm{m} ; \mathrm{B}, \mathrm{D}, \mathrm{F}$ and $\mathrm{H}$, $63 \mu \mathrm{m}$; E, $600 \mu \mathrm{m}$.
Table 2). During both these instances, proTRH mRNAs were normalised in the hypothalamus (Fig. 5). Also, TRHR1 mRNA levels were reduced towards control values in the hypothalamus (Fig. 1). Together, these observations indicate that suckling is the major modulator of the TRH/TRHR1 system in the hypothalamus.

PRL may, however, contribute to the regulation of TRHR 1 expression. The present results show that continued suckling is critical to maintain both plasma PRL levels as well as proTRH and TRHR 1 mRNA expression in the hypothalamus (group III versus group II: Table 2, Figs 1 and 5). However, although bromocriptine
Table 2 Plasma concentrations of PRL. Measurements of plasma $P R L$ concentrations in control (group I) and in lactating rats with (group IV) and without (groups II and III) bromocriptine treatment (see Materials and methods). The results are given as mean values \pm S.E.M. of 5-9 animals per group $(n)$.

\begin{tabular}{|c|c|c|c|c|}
\hline & \multicolumn{4}{|c|}{ Group } \\
\hline & 1 & II & III & IV \\
\hline $\begin{array}{l}\text { PRL } \\
\text { (ng/ml) }\end{array}$ & $\begin{array}{c}2.27 \pm 0.12 \\
(6)\end{array}$ & $\begin{array}{c}62.0 \pm 7.0 \\
(9)\end{array}$ & $\begin{array}{c}9.62 \pm 0.57 \\
(6)\end{array}$ & $\begin{array}{c}22.2 \pm 2.6 \\
(5)\end{array}$ \\
\hline
\end{tabular}

$P<0.001$, group II versus group I; $P<0.01$, group II versus group III; $P<0.05$, group I versus groups III or IV and group II versus group IV. 
Table 3 TRHDE mRNA in rat pituitary gland and hypothalamus quantified by using real time RT-PCR. Values are relative to those of $\beta$-actin and normalised to the control group (group I). The results represent a mean values \pm S.E.M. of $3-6$ rats $(n)$.

\begin{tabular}{lcccr}
\hline & \multicolumn{4}{c}{ Group } \\
\cline { 2 - 5 } Tissue & I & II & III & IV \\
\hline Pituitary & $1.00 \pm 0.060(6)$ & $1.20 \pm 0.15(5)$ & $0.87 \pm 0.082(6)$ & $0.95 \pm 0.28(3)$ \\
Hypothalamus & $1.00 \pm 0.094(6)$ & $1.10 \pm 0.087(3)$ & N.D. & $0.71 \pm 0.17(6)$ \\
\hline
\end{tabular}

N.D., not determined.

decreases the PRL concentration in the plasma of lactating animals, the hormone concentration does not decrease as much as in animals in group III. Furthermore, the decrease in TRHR 1 expression is not as pronounced in group IV as in group III, and this can be accounted for by the higher PRL levels in group IV.

It has been established that the primary structure of hypothalamic and pituitary PRL is identical. In the present experiments we cannot differentiate between the effects of circulating and locally produced hypothalamic PRL since circulatory hormone has access to hypothalamic neurons through the choroid plexi of the brain ventricles (29). Circulating PRL may also enter the brain by retrograde blood flow from the anterior pituitary to the hypothalamus $(30,31)$. Hence, it is not possible to determine whether the changes in TRHR1 mRNA expression may be attributed to the higher levels of plasma PRL in group IV compared with group III animals, or are a result of locally synthesised PRL or both. Both the long and short form of the PRL receptor (PRLR) (32) are present in the hypothalamus and in the pituitary. It is possible that hypothalamic PRL also acts as an autocrine/paracrine hormone since SON and PVN were found to express high levels of PRLR in lactating, but not in dioestrous, rats (33).

Suckling-initiated reduction in the tonic dopamine inhibition has been suggested not to be the only mechanism by which PRL secretion is enhanced during lactation, as summarised by Martinez de la Escalera and Weiner (34). In this context, the up-regulation of proTRH/TRHR1 mRNAs in the SON and PVN which contain PRL and PRL receptor positive neurons during lactation $(35,36)$ may be part of a local feedback loop to enhance hypothalamic stimulation of PRL secretion from the pituitary. Our data also support the possibility that a similar mechanism may prevail in the pituitary where lactotrophs, which contain receptors for dopamine and other hypothalamic hormones known to affect PRL secretion, show up-regulation of TRHR1.

Binding of PRL to its receptor leads to receptor dimerisation and activation of the Jak/STAT pathway, reviewed in Freeman et al. (37). The consensus DNA motif recognized by STAT1, STAT3 and STAT5 homoor heterodimers is termed GAS ( $\gamma$-interferon activated sequence) and consists of the palindromic sequence;
TTCxxxGAA (38). Re-examining the human TRHR promoter sequence (39), we found one perfect match of the GAS consensus motif in position -26 to -18 relative to the translation start site and several potential binding sites containing only one mismatch. Hence, increased transcription of the TRHR1 gene may occur after PRL activation of the Jak/STAT pathway. It is also of interest that we have previously described binding of the glucocorticoid receptor to the human TRHR promoter (40) as this receptor has been proposed to interact with STAT to initiate cell- and cytokine-specific responses $(41,42)$. In the pituitary, the anterior pituitary-specific transcription factor Pit-1 is a candidate for regulation of the TRHR gene, since we have previously demonstrated that Pit-1 binds to the human TRHR gene promoter in a cell type-specific manner (39).

Bromocriptine acts on dopamine D2 receptors which are also present in the pituitary (43). The detailed molecular actions of bromocriptine (2-bromo-alphaergocryptine), a semi-synthetic ergot alkaloid with long-term stimulatory effects on dopamine D2 receptors, are not known. Since bromocriptine is able to penetrate the blood-brain barrier (44), the drug will have access to most dopaminergic systems in the CNS. It is clinically used to reduce hyperprolactinaemia and to inhibit milk secretion, as well as to treat, for example, Parkinson's disease and acromegaly (4550). TRHR 1 mRNA expression is highly up-regulated in the pituitary after treatment with bromocriptine (Fig. 4). The molecular mechanisms for increased TRHR1 mRNA levels are unknown, but could be a way to compensate for the decrease in plasma PRL concentration in an effort to make the pituitary more responsive to TRH. Maintained plasma PRL concentrations would also help to sustain milk production and lactation. It is known that activated TRHR 1 signals through the $\mathrm{G} \alpha \mathrm{q} / 11$ and a subset of $\mathrm{G} \alpha$ s heterotrimeric G-proteins (51-54). It is therefore of interest that Gaq/11-deficient mice where the PRL release axis was normal, did not display any maternal behaviour including nursing (55). We have previously shown that many signal transduction effects caused by TRH in pituitary adenoma cells (GH cells) in culture, are inhibited or abolished by bromocriptine. These effects could be explained by inhibition of G-protein actions $\left(\mathrm{G}_{\mathrm{i} 2}, \mathrm{G}_{\mathrm{o}}, \mathrm{G}_{\mathrm{s}}\right.$ and $\left.\mathrm{G}_{\mathrm{q} / 11}\right)(56,57)$. In addition to 
these TRH-inhibitory actions, bromocriptine has also been shown to stimulate the pituitary TRH degrading enzyme (TRHDE), a TRH-specific ectoenzyme responsible for the inactivation of TRH (58). This is another mechanism whereby bromocriptine would be able to decrease the biological effect of TRH at the pituitary level. However, no significant change in TRHDE mRNA expression (Table 3) was detected in the hypothalamus or in the pituitary between the different experimental groups. Thus, the changes in proTRH mRNA expression reported in this study are not influenced by, or are secondary to, altered TRH half life.

In this study we examined, in particular, the PVN, SON, LPO and LM, as well as the SNC, which is a mesencephalic region enriched in dopaminergic cells located adjacent to the hypothalamus. The reason for this was that neurons in these areas showed a high expression of mRNA coding for proTRH and/or TRHR1, as documented in histological in situ analyses. The up-regulation of proTRH and/or TRHR 1 mRNA in the different nuclei was mainly a result of more cells expressing proTRH/TRHR1 mRNA since the results from cell-counting paralleled the results from the image processing.

Our data show that TRHR1 mRNA expression is upregulated in the SON and the LM during suckling. TRHR1 expression is also slightly increased in the PVN. This is of great interest since oxytocin and vasopressin are both produced in the SON and the PVN (59, 60). They are important, for example, in milk secretion, fluid balance and nesting behaviour (61). Intracerebroventricular administration of TRH leads to increased concentrations of oxytocin and vasopressin in the hypothalamus and in the posterior pituitary in nursing rats (62). Noradrenalin and serotonin are known to control arginine-vasopressin and oxytocin secretion in the systemic circulation, and have recently been shown to do the same in the PVN and the SON in mouse (63). However, TRH had no effect on noradrenalin release from neurons of the PVN (64). TRH may still act by modulating release of, for example, serotonin from these nuclei and noradrenalin from the SON. TRH, noradrenalin and serotonin may also act in parallel giving an additive or synergetic effect on oxytocin and vasopressin release.

In addition, the nerve cells located in these nuclei are known to project fibres to other hypothalamic regions in particular, but also to distinct, extra-hypothalamic brain areas. Accordingly, TRH may, in relation to nursing, modulate a number of CNS functions through activation of TRHR1 (65). The present findings extend previous observations of Uribe, Sanchez and colleagues $(15,66)$ that showed that mRNA for proTRH was up-regulated in the PVN under a number of physiological conditions such as lactation and stress associated with freezing.

In our study, TRHR1 mRNA expression was reduced in the amygdala in group II animals (Table 1), but was normalised $24 \mathrm{~h}$ after termination of suckling (group III). The nerve cells located in this area are known to project fibres to other hypothalamic regions and/or to distinct, extra-hypothalamic brain areas, thereby making it possible to influence a number of brain functions associated with motherhood and nursing. These possibilities indicate a functional link between the hypothalamus and the amygdala in the suckling-lactation reflex. In contrast, no significant changes were found between the experimental groups in the hippocampus, cortex or cerebellum, indicating that these areas do not participate in this response. ProTRH mRNA expression did not show any significant changes between the groups in the thalamus, cortex or cerebellum (data not shown).

Our results indicate that suckling through neuronal activation stimulates the hypothalamic nuclei to increase synthesis and release of proTRH and up-regulates the TRHR1 system. TRH acting through TRHR1 may modulate the synaptic circuitry which is involved in lactation and may also be important for the grooming behaviour of rats. Taken together, the present and earlier results open up an emerging understanding of the involvement of TRH and TRHR1 in the physiology and pharmacology of suckling-induced lactation at the pituitary and the hypothalamic levels.

\section{Acknowledgements}

We thank Professor Egil Haug, Aker Hormone Laboratory for analysis of rat prolactin. This work was supported by the Norwegian Cancer Society, the Norwegian Research Council (NFR), Anders Jahre Foundation for Promotion of Science, Oslo, Norway and The Novo Nordisk Foundation, Copenhagen, Denmark.

\section{References}

1 Gautvik KM, Weintraub BD, Graeber CT, Maloof F, Zuckerman JE \& Tashjian AH Jr. Serum prolactin and TSH: effects of nursing and pyroGlu-His-ProNH $\mathrm{N}_{2}$ administration in postpartum women. Journal of Clinical Endocrinology and Metabolism 197337 135-139.

2 Gautvik KM, Tashjian AH Jr, Kourides IA, Weintraub BD, Graeber CT, Maloof F, Suzuki K \& Zuckerman JE. Thyrotropinreleasing hormone is not the sole physiologic mediator of prolactin release during suckling. New England Journal of Medicine $19742901162-1165$

3 Grosvenor CE, Mena F \& Whitworth NS. Evidence that the dopaminergic prolactin-inhibiting factor mechanism regulates only the depletion-transformation phase and not the release phase of prolactin secretion during suckling in the rat. Endocrinology $1980106481-485$.

4 de Greef WJ, Klootwijk W, Karels B \& Visser TJ. Levels of dopamine and thyrotropin-releasing hormone in hypophysial stalk blood during an oestrogen-stimulated surge of prolactin in the ovariectomized rat. Journal of Endocrinology $1985 \mathbf{1 0 5} 107-112$.

5 Mori M \& Yamada M. Thyroid hormones regulate the amount of thyrotropin-releasing hormone in the hypothalamic median eminence of the rat. Journal of Endocrinology 1987114 443-448.

6 Haisenleder DJ, Ortolano GA, Dalkin AC, Yasin M \& Marshall JC. Differential actions of thyrotropin (TSH)-releasing hormone 
pulses in the expression of prolactin and TSH subunit messenger ribonucleic acid in rat pituitary cells in vitro. Endocrinology 1992 $1302917-2923$.

7 Aizawa T \& Greer MA. Delineation of the hypothalamic area controlling thyrotropin secretion in the rat. Endocrinology 1981109 $1731-1738$.

8 de Greef WJ \& Visser TJ. Evidence for the involvement of hypothalamic dopamine and thyrotropin-releasing hormone in suckling-induced release of prolactin. Journal of Endocrinology 1981 $91213-223$.

9 de Greef WJ, Voogt JL, Visser TJ, Lamberts SW \& van der Schoot P. Control of prolactin release induced by suckling. Endocrinology $1987121316-322$

10 Leblanc H, Lachelin GC, Abu-Fadil S \& Yen SS. Effects of dopamine infusion on pituitary hormone secretion in humans. Journal of Clinical Endocrinology and Metabolism 197643 668-674.

11 Scanlon MF, Weightman DR, Shale DJ, Mora B, Heath M, Snow MH, Lewis M \& Hall R. Dopamine is a physiological regulator of thyrotropin (TSH) secretion in normal man. Clinical Endocrinology $1979107-15$.

12 Blake CA. Stimulation of pituitary prolactin and TSH release in lactating and proestrous rats. Endocrinology 197494 503-508.

13 Riskind PN, Millard WJ \& Martin JB. Evidence that thyrotropinreleasing hormone is not a major prolactin-releasing factor during suckling in the rat. Endocrinology $1984115312-316$.

14 Sheward WJ, Fraser HM \& Fink G. Effect of immunoneutralization of thyrotropin-releasing hormone on the release of thyrotropin and prolactin during suckling or in response to electrical stimulation of the hypothalamus in the anaesthetized rat. Journal of Endocrinology 1985106 113-119.

15 Uribe RM, Redondo JL, Charli JL \& Joseph-Bravo P. Suckling and cold stress rapidly and transiently increase TRH mRNA in the paraventricular nucleus. Neuroendocrinology 199358 140-145.

16 Walaas SI, Nairn AC \& Greengard P. Regional distribution of calcium- and cyclic adenosine $3^{\prime}, 5^{\prime}$-monophosphate-regulated protein phosphorylation systems in mammalian brain. I. Particulate systems. Journal of Neuroscience 19833 291-301.

17 Paxinos G, Watson C. The Rat Brain in Stereotaxic Coordinates. San Diego: Academic Press Inc., 1998.

18 Haug E \& Gautvik KM. Radioimmunoassay of rat prolactin and its use in measuring prolactin production by cultured pituitary cells Acta Endocrinologica $1976 \mathbf{8 2} 282-297$.

19 Chirgwin JM, Przybyla AE, MacDonald RJ \& Rutter WJ. Isolation of biologically active ribonucleic acid from sources enriched in ribonuclease. Biochemistry 197918 5294-5299.

20 Sambrook J, Fritsch EF \& Maniatis T. Molecular Cloning, A Laboratory Manual. New York: Cold Spring Harbor Laboratory Press, 1989.

21 Matre V, Karlsen HE, Wright MS, Lundell I, Fjeldheim $\AA-K$, Gabrielsen OS, Larhammar D \& Gautvik KM. Molecular cloning of a functional human thyrotropin-releasing hormone receptor. Biochemical and Biophysical Research Communications 1993195 $179-185$.

22 Cao J, O'Donell D, Vu H, Payza K, Pou C, Godbout C, Jakob A, Pelletier M, Lembo P, Ahmad S \& Walker P. Cloning and characterization of a cDNA encoding a novel subtype of rat thyrotropin-releasing hormone receptor. Journal of Biological Chemistry $199827332281-32287$.

23 Itadani H, Nakamura T, Itoh J, Iwaasa H, Kanatani A, Borkowski J, Ihara M \& Ohta M. Cloning and characterization of a new subtype of thyrotropin-releasing hormone receptors. Biochemical and Biophysical Research Communications 1998250 68-71.

24 Ovstebo R, Foss Haug KB, Lande K \& Kierulf P. PCR-based calibration curves for studies of quantitative gene expression in human monocytes: development and evaluation. Clinical Chemistry $200349425-432$.

25 Hoover F \& Goldman D. Temporally correlated expression of nAChR genes during development of the mammalian retina. Experimental Eye Research 199254 561-571.

26 Torp R, Hoover F, Danbolt NC, Storm-Mathisen J \& Ottersen OP. Differential distribution of the glutamate transporters GLT1 and
rEAAC1 in rat cerebral cortex and thalamus: an in situ hybridization analysis. Anatomy and Embryology 1997195 317-326.

27 Clark BJ, Fluckiger E, Lowe DM \& Vigouret JM. How does bromocriptine work? Triangle $1978121-32$.

28 Nillni EA, Aird F, Seidah NG, Todd RB \& Koenig JI. PreproTRH(178-199) and two novel peptides (pFQ7 and pSE14) derived from its processing, which are produced in the paraventricular nucleus of the rat hypothalamus, are regulated during suckling. Endocrinology 2001142 896-906.

29 Mangurian LP, Walsh RJ \& Posner BI. Prolactin enhancement of its own uptake at the choroid plexus. Endocrinology 1992131 $698-702$.

30 Mezey E \& Palkovits M. Two-way transport in the hypothalamohypophyseal system. In Frontiers in Neuroendocrinology, pp 1-29. Eds WF Ganong \& L Martini. New York: Raven Press, 1982.

31 Oliver C, Mical RS \& Porter JC. Hypothalamic-pituitary vasculature: evidence for retrograde blood flow in the pituitary stalk. Endocrinology 1977101 598-604.

32 Chiu S, Koos RD \& Wise PM. Detection of prolactin receptor (PRL-R) mRNA in the rat hypothalamus and pituitary gland. Endocrinology 1992130 1747-1749.

33 Grattan DR. The actions of prolactin in the brain during pregnancy and lactation. Progress in Brain Research 2001133 153-171.

34 Martinez de la Escalera G \& Weiner RI. Dissociation of dopamine from its receptor as a signal in the pleiotropic hypothalamic regulation of prolactin secretion. Endocrine Reviews 199213 241-255.

35 Torner L, Maloumby R, Nava G, Aranda J, Clapp C \& Neumann ID. In vivo release and gene upregulation of brain prolactin in response to physiological stimuli. European Journal of Neuroscience $2004191601-1608$.

36 Pi X-J \& Grattan DR. Differential expression of the two forms of prolactin receptor mRNA within microdissected hypothalamic nuclei of the rat. Molecular Brain Research 199859 1-12.

37 Freeman ME, Kanyicska B, Lerant A \& Nagy G. Prolactin: structure, function, and regulation of secretion. Physiological Reviews $2000801523-1631$.

38 Horseman ND \& Yu-Lee LY. Transcriptional regulation by the helix bundle peptide hormones: growth hormone, prolactin, and hematopoietic cytokines. Endocrine Reviews 199415 627-649.

39 Matre V, Hovring PI, Orstavik S, Frengen E, Rian E, Velickovic Z, Murray-McIntosh RP \& Gautvik KM. Structural and functional organization of the gene encoding the human thyrotropin-releasing hormone receptor. Journal of Neurochemistry $1999 \mathbf{7 2} 40-50$.

40 Hovring PI, Matre V, Fjeldheim AK, Loseth OP \& Gautvik KM. Transcription of the human thyrotropin-releasing hormone receptor gene - analysis of basal promoter elements and glucocorticoid response elements. Biochemical and Biophysical Research Communications 1999257 829-834.

41 Stoecklin E, Wissler M, Gouilleux F \& Groner B. Functional interactions between Stat 5 and the glucocorticoid receptor. Nature $1996383726-728$.

42 Stoecklin E, Wissler M, Moriggl R \& Groner B. Specific DNA binding of Stat5, but not of glucocorticoid receptor, is required for their functional cooperation in the regulation of gene transcription. Molecular and Cellular Biology 199717 6708-6716.

43 Johansen PW, Paulssen RH, Bjoro T, Gautvik KM \& Gordeladze JO. Distinct guanine nucleotide binding protein alpha-subunit receptor coupling in GH cell lines: effects of bromocriptine and hormones on effector enzyme modulation. Cellular Physiology and Biochemistry 200111 339-352.

44 Renodon A, Boucher JL, Sari MA, Delaforge M, Ouazzani J \& Mansuy D. Bromocriptine is a strong inhibitor of brain nitric oxide synthase: possible consequences for the origin of its therapeutic effects. FEBS Letters 1997406 33-36.

45 Camanni F, Massara F, Fassio V, Molinatti GM \& Muller EE. Effect of five dopaminergic drugs on plasma growth hormone levels in acromegalic subjects. Neuroendocrinology 197519 227-240. 
46 Cooke I, Foley M, Lenton E, Preston E, Millar D, Jenkins A, Obiekwe B, McNeilly A, Parsons J \& Kennedy G. The treatment of puerperal lactation with bromocriptine. Postgraduate Medical Journal 197652 (Suppl 1) 75-80.

47 Prysor-Jones RA \& Jenkins JS. Effect of bromocriptine, ergotamine and other ergot alkaloids on the hormone secretion and growth of a rat pituitary tumour. Journal of Endocrinology $1980 \mathbf{8 6}$ $147-153$

48 Johansen PW, Sand O, Iversen JG, Haug E \& Gautvik KM. Effects of bromocriptine on prolactin release, electrical membrane properties and transmembrane $\mathrm{Ca}^{2+}$ fluxes in cultured rat pituitary adenoma cells. Acta Endocrinologica 1986111 185-192.

49 Halse J, Harris AG, Kvistborg A, Kjartansson O, Hanssen E, Smiseth O, Djosland O, Hass G \& Jervell J. A randomized study of SMS 201-995 versus bromocriptine treatment in acromegaly: clinical and biochemical effects. Journal of Clinical Endocrinology and Metabolism 199070 1254-1261.

50 Jaffe CA \& Barkan AL. Treatment of acromegaly with dopamine agonists. Endocrinology and Metabolism Clinics of North America $199221713-735$.

51 Aragay AM, Katz A \& Simon MI. The G alpha q and G alpha 11 proteins couple the thyrotropin-releasing hormone receptor to phospholipase $\mathrm{C}$ in $\mathrm{GH} 3$ rat pituitary cells. Journal of Biological Chemistry 1992267 24983-24988.

52 Hsieh KP \& Martin TF. Thyrotropin-releasing hormone and gonadotropin-releasing hormone receptors activate phospholipase $\mathrm{C}$ by coupling to the guanosine triphosphate-binding proteins $\mathrm{Gq}$ and G11. Molecular Endocrinology 19926 1673-1681.

53 Gautvik KM, Gordeladze JO, Janhsen T, Haug E, Hansson V \& Lystad E. Thyroliberin receptor binding and adenylyl cyclase activation in cultured prolactin-producing rat pituitary tumor cells (GH cells). Journal of Biological Chemistry $1983 \mathbf{2 5 8}$ 10304-10311.

54 Paulssen RH, Paulssen EJ, Gautvik KM \& Gordeladze JO. The thyroliberin receptor interacts directly with a stimulatory guaninenucleotide-binding protein in the activation of adenylyl cyclase in $\mathrm{GH} 3$ rat pituitary tumour cells. Evidence obtained by the use of antisense RNA inhibition and immunoblocking of the stimulatory guanine-nucleotide-binding protein. European Journal of Biochemistry $1992 \mathbf{2 0 4} 413-418$.

55 Wettschureck N, Moers A, Hamalainen T, Lemberger T, Shcutz G \& Offermanns S. Heterotrimeric G proteins of the Gq/11 family are crucial for the induction of maternal behaviour in mice. Molecular and Cellular Biology 200424 8048-8054.

56 Johansen PW, Clausen OP, Haug E, Fossum S \& Gautvik KM. Effects of bromocriptine on cell cycle distribution and cell morphology in cultured rat pituitary adenoma cells. Acta Endocrinologica 1985 $110319-328$.

57 Johansen PW, Haug E \& Gautvik KM. Effects of bromocriptine on hormone production and cell growth in cultured rat pituitary cells. Acta Endocrinologica $1985110200-206$.

58 Vargas MA, Bourdais J, Sanchez S, Uriostegui B, Moreno E, Joseph-Bravo P \& Charli JL. Multiple hypothalamic factors regulate pyroglutamyl peptidase II in cultures of adenohypophyseal cells: role of the cAMP pathway. Journal of Neuroendocrinology $199810199-206$.

59 Cunningham ET Jr \& Sawchenko PE. Reflex control of magnocellular vasopressin and oxytocin secretion. Trends in Neuroscience 199114 406-411.

60 Aguilera G, Lightman SL \& Kiss A. Regulation of the hypothalamic-pituitary-adrenal axis during water deprivation. Endocrinology $1993132241-248$.

61 Lim MM, Wang Z, Olazabal DE, Ren X, Terwilliger EF \& Young LJ. Enhanced partner preference in a promiscuous species by manipulating the expression of a single gene. Nature $2004 \mathbf{4 2 9}$ 754-757.

62 Ciosek J \& Guzek JW. Thyrotropin-releasing hormone affects the oxytocin, vasopressin and prolactin release in female rats during midlactation: relation to suckling. Journal of Physiology and Pharmacology 1998 49 135-150.

63 Vacher CM, Frétier P, Crémion C, Calas A \& Hardin-Pouzet H. Activation by serotonin and noradrenaline of vasopressin and oxytocin expression in the mouse paraventricular and supraoptic nuclei. Journal of Neuroscience 200222 1513-1522.

64 Brunetti L, Orlando G, Michelotto B, Recinella L \& Vacca M. Cocaine- and amphetamine-regulated transcript peptide-(55102) and thyrotropin releasing hormone inhibit hypothalamic dopamine release. European Journal of Pharmacology $2000 \mathbf{4 0 9}$ 103-107.

65 Yamada M, Satoh T \& Mori M. Mice lacking the thyrotropinreleasing hormone gene: what do they tell us? Thyroid 200313 1111-1121.

66 Sanchez E, Uribe RM, Corkidi G, Zoeller RT, Cisneros M, Zacarias M, Morales-Chapa C, Charli JL \& Joseph-Bravo P. Differential responses of thyrotropin-releasing hormone (TRH) neurons to cold exposure or suckling indicate functional heterogeneity of the TRH system in the paraventricular nucleus of the rat hypothalamus. Neuroendocrinology 2001 74 407-422.

Received 21 October 2004

Accepted 4 February 2005 